\title{
Tobacco Trading Arrangements: Prospect of Justice for Tobacco Farmers in Java
}

\author{
Nanik Prasetyoningsih \\ Faculty of Law \\ Universitas Muhammadiyah Yogyakarta \\ Yogyakarta, Indonesia \\ e-mail: nprasetyoningsih@gmail.com
}

\begin{abstract}
Tobacco trading is a tobacco marketing system from farmers to consumers. In the global trade system, local tobacco farmers compete with tobacco manufacturers from abroad. Unfortunately, government performance is unsatisfying regarding the management of tobacco trading mechanism. This study aimed to determine and examine the regulation of the tobacco trade in Indonesia. This was a systematic qualitative research, using the analytical comparison to provide empirical generalizations. The study was based on previous research conducted in Sumenep, Pamekasan, Boyolali, Wonosobo, and Temanggung. The data were compared to review local government policies in regulating tobacco trading system both at the central and local government. The results showed that Indonesia does not have a standard regulation of tobacco trading system. The Farmers Protection Act does not significantly affect the prosperity of tobacco farmers. The law becomes meaningless, as there is a provision that foreign investors are prohibited from purchasing tobacco directly from farmers. Tobacco farmers are facing internal and external conditions simultaneously. At the lowest position of tobacco trading system chain, tobacco farmers are the most disadvantaged and exploited by tobacco industries. The government shall take actions to protect and empower tobacco farmers by promoting the implementation of any relevant laws.
\end{abstract}

Keywords-government, tobacco farmers, tobacco trading system

\section{INTRODUCTION}

Tobacco trading is a tobacco marketing system from farmers to consumers. In the global trade system, local tobacco farmers compete with tobacco manufacturers from abroad. Indonesia's tobacco industry requires about 300,000 tons per year, and the industry remains dependent on tobacco imports. However, the government has not developed any program to control the import of tobacco to protect local farmers who have been heavily affected by the influx of imported tobacco. The government performance is unsatisfying regarding the management of tobacco trading mechanism, causing tobacco farmers to be the most disadvantaged party in the chain of tobacco trade.

Indonesian Tobacco is one of the agricultural resources that has an important role in the national economy. Indonesia as a tobacco-producing country in the world ranks the 6th after China, Brazil, India, the United States, and Malawi [1]. Tobacco farming lands in Indonesia spread over several provinces and the largest is in East Java Province, i.e. $50.6 \%$. Other tobacco farming lands are in Central Java, West Nusa Tenggara, West Java, South Sulawesi, North Sumatra, and Yogyakarta Special Region[1].

Tobacco varieties have long become one of Indonesia's main export commodities and provided income to the players. The national tobacco industry absorbs quite significant labor. In 2015, 4.15 million workers worked in the tobacco industry, of which 93.77 percent were absorbed by farming activities including post-harvest and 6.23 percent in the cigarette processing sector[2]. The role of tobacco commodities that is quite real in the national economy is as a source of the state revenue from the excise tax which continues to experience a year-over-year increase[3]. Excise tax on a cigarette is still the mainstay of the state revenue because it contributes 96 percent to the total state revenue from excise tax [2]. The number of tobacco farmers in 2015 was around 689,360 farmers with a total area of 221,000 acres spread across 15 provinces. However, tobacco farmers' bargaining position is still low because the tobacco market is oligopsonistic where prices are determined by the tobacco industry, and the price fluctuations are very high and tend to be erratic [2]. Tobacco farmers are still very dependent on the tobacco industry because there has been no diversification of products from tobacco materials. So far tobacco leaves are only processed into cigarettes, whereas actually the diversification of tobacco products can be processed into basic chemicals that can be used as pesticides, drugs, cosmetics, and materials for pharmaceutical industry.

Tobacco farmers are Indonesians who have the right to be protected by the state. The fifth principle of Pancasila and the Preamble of the 1945 Constitution clearly state that social justice for all Indonesian people is one of the basic philosophies of nation-building. Every citizen has the right to his welfare. Thus, every Indonesian citizen including tobacco farmers has the right and is obliged according to his ability to participate in the efforts to improve their welfare. So far tobacco farmers have contributed significantly to the agricultural development and rural economic development. Farmers as development actors need to be given protection and empowerment. In 2013 the State issued Law Number 19 of 2013 concerning the Protection and Empowerment of Farmers to provide protection to farmers. The Farmer 
of welfare, quality, and life of farmers.

However, five years after the issuance of the Farmer Protection and Empowerment Act, the life and welfare of tobacco farmers have not changed. Tobacco farmers are still the most disadvantaged in the chain of the tobacco trade. Tobacco farmers are not independent that they cannot improve the level of welfare, quality, and life because the tobacco industry is the one that fully determines the price of tobacco. Another problem faced by tobacco farmers is a shrinking tobacco market because the government does not control tobacco imports. The tobacco industry prefers to use imported tobacco because the price of domestic tobacco is more expensive. Increased cigarette production should be an advantage for tobacco farmers, but the government prefers to import rather than to increase domestic tobacco production. However, the policies of the two ministries are different in terms of tobacco import. The Ministry of Agriculture seeks to improve the quality and production of tobacco farming, but the Ministry of Trade precisely does not restrict tobacco import. The demand for tobacco products that continues to increase is finally distracted by the import policy. As a result, a high tobacco demand is not directly proportional to the fate of tobacco farmers. They do not enjoy the maximum benefit from the situation [4]. Ironically, the luxury of the tobacco industry does not have an impact on improving the welfare of tobacco farmers.

It is important to study the relationship among the government, cigarette industry, and tobacco farmers from various aspects. The practice of oligopsonistic tobacco trading is very detrimental to tobacco farmers. Government regulations have so far not been quite effective to weaken the dominance of the tobacco industry in the chain of tobacco trading systems and provide protection for tobacco farmers. The regulations have not optimally promoted tobacco farmers to have a higher bargaining position and certainty in carrying out their farming business.

First of all, this article describes the mechanism of tobacco trading in the tobacco-producing regions such as Sumenep, Pamekasan, Boyolali, Wonosobo, and Temanggung. In discussing the tobacco trading system mechanism, it also views how the government plays a role in controlling the tobacco trading system and how the tripartite relationship among the government, Cigarette Industry and tobacco farmers in the tobacco trading system. The second discussion is an analysis of the existing regulations and their effectiveness, especially in promoting protection and empowerment for tobacco farmers. The discussion ends with the author's recommendations regarding any efforts to make to promote the protection and increase the welfare of tobacco farmers.

\section{METHODS}

This research was a systematic qualitative research, aimed to figure out the policies of the tobacco trading system in Java Island especially in the locations where tobacco plantations are located such as Sumenep, Pamekasan, Boyolali, Wonosobo, and Temanggung. This research analyzed and interpreted textual data from previous research to build generalization of the government policies
Researgh yolume 172arrangement of the tobacco trading mechanism. The researcher used a qualitative research because this could gain a better understanding of the complex reality of the tobacco trading system and its implication to the tobacco farmers.

\section{RESULTS AND DISCUSSION}

Results and Discussion contains result of data analysis (but does not contain raw data nor print-screen of analysis) which is presented in table or figure. Sufficient and comprehensive data should be presented to give complete information and allow the reader to interpret the results. The text should explain or elaborate the tabular data, but numbers should not be repeated extensively within the text. Discussion should be consistent and should interpret the results clearly and concisely, address logically mechanism and explanation, supported with suitable literatures. The discussion should show relevance between the results and the field of investigation and/or hypotheses.

\section{A. Tobacco Trading System Mechanism}

The trading system refers to a particular commodity trading system that includes the processes and conditions that occur, starting from marketing to commodities and finally to consumers [5]. The tobacco trading system used in this text refers to the tobacco marketing system from farmers to consumers [2].

Tobacco and its processed products are one of the most important trades and industrial commodities in Indonesia. This commodity is also a national commodity and industry that has survived since the colonial era [6]. However, tobacco in Indonesia is not categorized as a superior commodity determined by the state so that the government does not have a national policy that specifically regulates tobacco commodities. Tobacco is positioned as a free item which is not regulated by the trade system. The price of tobacco is determined based on the quality of tobacco and the needs of the tobacco industry, but the government does not issue any regulation in this matter [2]. In 2006 there was a significant increase in the price of tobacco leaves but it did not have implications on the welfare of tobacco farmers because the price of tobacco leaves was determined by the grades. Grade (quality) price of tobacco leaves is determined unilaterally [3].

Tobacco is one of the plantation crops cultivated by Indonesian farmers, especially in Java [3]. In Pamekasan and Sumenep, the tobacco trading system is regulated in local regulations but it is not well implemented. For example, the Local Government of Pamekasan Regency issued Local Regulation Number 6 of 2012 concerning Implementation Guidelines for the Purchasing and Exploitation of Tobacco and the Local Government of Sumenep issued Local Regulation Number 6 of 2012 concerning Administration of Madura Tobacco. However, these two regulations do not regulate tobacco prices and tobacco leaf purchase schedules at all. Instead, they only regulate the freedom of buyers (tobacco industry) to buy Madura tobacco from any party and buyers' obligation to report the opening and closing schedule of purchases to the local government. 
PRAtisS absence of regulation regarding 'pringing Engnerin purchase schedule creates two problems for tobacco farmers, namely: (1) the tobacco industry has a very strong bargaining position because it determines the tobacco price since the government does not act as the price regulator; and (2) tobacco farmers will be able to sell their tobacco only if the factory opens purchase. Both of these problems lead to two models of tobacco trading system, namely oligopsony and monopsony. Oligopsony is a condition where the price of tobacco is based on the needs of the factory so that the factory determines the price of tobacco unilaterally, while monopsony is a condition where the process of selling tobacco depends on the opening of the factory's purchase schedule. Tobacco farmers cannot determine either the tobacco sales schedule or the number of factories that open the purchase schedule. Tobacco prices will depend on the quality of the product and the tastes according to a single buyer. The tobacco market in Madura is very uncompetitive and does not benefit tobacco farmers. The government does not regulate tobacco trading system in local regulations, but only monitors and supervises purchases in the warehouse.

On the other hand, tobacco farmers also face problems caused by a long chain of tobacco trade in determining the final price of tobacco. The cigarette industry does not buy tobacco directly from farmers, but through buyers or warehouses, the large-scale trustees of tobacco factories. The chain under the middleman is a smaller trader called "Bandol" or an intermediary. "Bandol" helps farmers in entering tobacco into the factory warehouse or middleman (tengkulak) [2]. There are two types of tobacco purchases carried out by Bandol, namely buying plants directly (slash) and buying chopped tobacco [7]. There are two types of Bandol, namely free Bandol and bound Bandol. Free Bandol is a trader who buys tobacco from farmers and has free to sell it to any warehouse. On the other hand, bound Bandol is a trader who could only sell tobacco from farmers to one particular skipper. Above Bandol is "Juragan", the warehouse owner who is trusted by the factory to buy tobacco from Bandol in accordance with the required tobacco criteria. Warehouses or factories are cigarette companies [8].

Middlemen as factory partners determine the price, and this is an oligopsonistic market, making farmers unable to enter the factory. The results of research conducted by Rokhmah [9] and Rachmad [10] found that tobacco pricing is a speculative transaction, meaning that profit-seeking motive of the middlemen is more dominant because the transaction does not end with the delivery of goods, so that prices are fixed regardless of the quality, so farmers have no bargaining power [4].

The quality of tobacco is determined by tobacco quality assessor who goes to the factory or warehouse named "Grader". A Grader is a factory trusted person who is very experienced and has the authority to determine the price of tobacco. There are three qualities assessed, namely smell, color, and stickiness. The number of actors involved in tobacco trading system causes tobacco farmers to become increasingly helpless, positioning them as the most
Researchantalume aztor in the chain of tobacco trading. The tobacco trading system in Madura is illustrated in Figure 1.

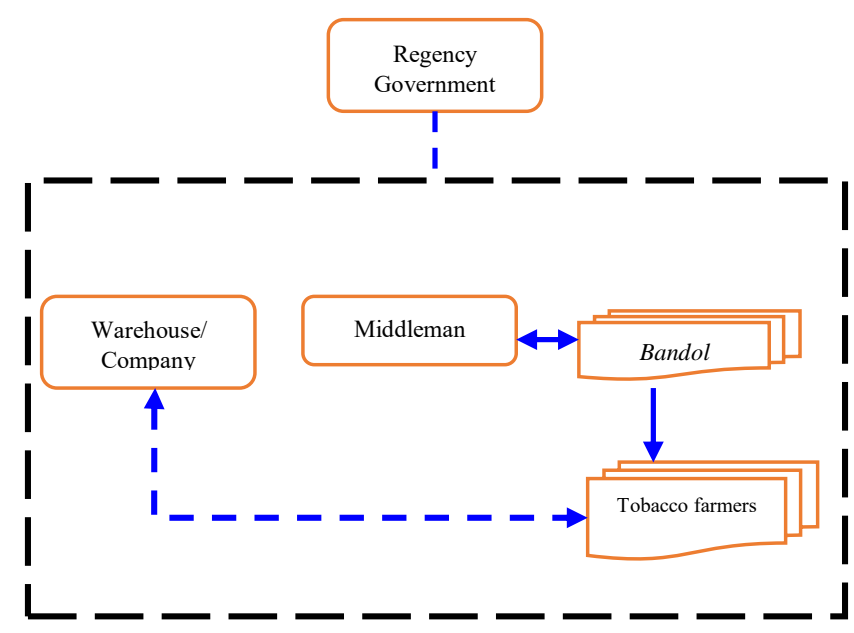

Figure 1. Tobacco Trading System in Madura

Source: Sofiyah, 2014.

In Wonosobo and Boyolali, there is no Local Government intervention in the tobacco trading system. The Local Government does not have any regulations to regulate the tobacco trading system. The tobacco trading system is completely ruled by the market and the price is also determined by the company. The actors involved in the tobacco trading system in Wonosobo and Boyolali are also the same as those in Sumenep and Pamekasan, listed from the strongest to the weakest actors, namely (1) Tobacco Company; (2) Intermediary of the Factory or Bandol; and (3) Tobacco farmers. Bandol in Wonosobo and Boyolali only buy chopped tobacco [11]. The Tobacco Purchase Channel in Wonosobo is shown in Figure 2 and Figure 3, and the purchase channel in Boyolali is illustrated in Figure 4.

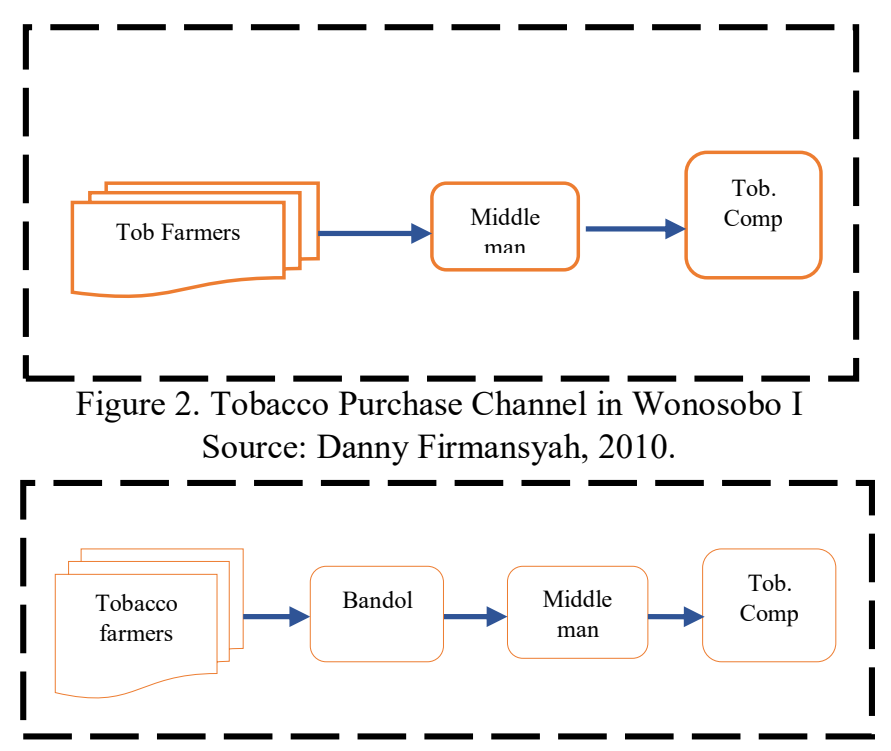

Figure 3. Tobacco Purchase Channel in Wonosobo II Source: Danny Firmansyah, 2010. 


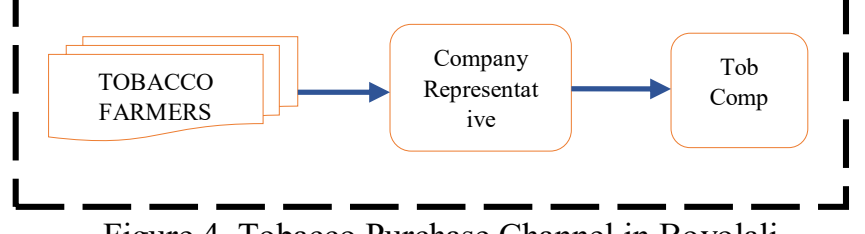

Figure 4. Tobacco Purchase Channel in Boyolali Source: Danny Firmansyah, 2010.

Unlike the facts in the three regions mentioned above, that tobacco farmers are not involved in determining tobacco prices, the tobacco farmers in Temanggung have a better bargaining position since they are involved in determining the tobacco price. However, in Temanggung the tobacco trade system still uses a monopsonistic system, meaning that there is a large number of sellers and a small number of buyers. In this condition, the bargaining position of farmers is very weak, especially for quality reasons, excess stocks and so on [12]. Based on these reasons, tobacco farmers are involved in the determination of the tobacco price together with cigarette manufacturers, middlemen, local representatives, and the Trade and Industry Office [13].

The process of tobacco product pricing is initiated by the tobacco company which states that the estimated tobacco prices are based on the costs of planting until tobacco production incurred farmers. Next, farmers, middlemen, and the local legislative council conduct discussions to approve or reject the price estimation from the tobacco company. During the pricing process, there is a bargaining process to determine the grade. If the price per grade has been agreed upon by the seller and buyer, the Trade and Industry Office and the local legislative council will announce the price per grade which serve as the benchmark price of the tobacco products. The grade is the market value of tobacco based on tobacco quality. If there is a long dry season, the grade will usually be high because the quality of tobacco is good, but during short dry season, the grade will decrease. This has become a benchmark for cigarette manufacturers in estimating the price that will be used as a benchmark grade [13].

There are 8 grades namely grade A, B, C, D, E, F, G, H. Grade A, B, C, D for rice field tobacco, while grades E, F, $\mathrm{G}, \mathrm{H}$ for dry tobacco. Grade prices of rice field tobacco range between IDR15,000 - IDR20,000 and each grade have a difference of IDR15,000. The estimated price of tobacco planted in fields or moor is higher than the price of rice field tobacco that starts from grade A IDR.15,000, B IDR.30,000, C IDR.45,000, and D IDR.60,000. The prices of grade E, F, $\mathrm{G}, \mathrm{H}$, are IDR.75,000, IDR.90,000, IDR.75,000 and IDR.120,000 respectively. The second factor to determine the price of tobacco is the number of stocks. A quantity is the amount of tobacco available [13].

The involvement of tobacco farmers in determining tobacco prices can be carried out in two ways namely direct involvement and indirect involvement. The indirect involvement is represented by the chairman of the partnership, the Indonesian Tobacco Farmers Association
Ressarfh), volympe 172 Trade and Industry Office, while the direct involvement is the involvement of representatives of farmers and tobacco company [13]

The involvement of tobacco farmers in determining tobacco prices in Temanggung shows that the tripartite has worked well. Thus, tobacco farmers can get maximum benefits. Tripartite practice in Temanggung can be used as a reference for other regions to be implemented. The tobacco trading system mechanism in Temanggung is democratic and transparent, meaning that each party has the same position and equal rights to express their opinions. The result of the agreed price per grade which is the benchmark price of tobacco products will be announced so that all tobacco farmers will know and anticipate it.

\section{B. Protection of Tobacco Farmers in Farmers Protection Act}

Tobacco farmers face internal and external conditions simultaneously, and this is very unpleasant. The internal issue faced by tobacco farmers is tobacco price fluctuation, causing an increase in production costs and reduce in farmers profits. Regarding the external issue, farmers face very stressful conditions namely the position of middlemen who unilaterally determine the quality, scale, and price of tobacco. The mechanism of the oligopsonistic tobacco trading system enables a number of warehouses owned by a small number of manufacturers to play a role in the "capacity" of the warehouse so that farmers are willing to sell their crops at the cheapest prices, positioning farmers as the disadvantaged party. A situation like this makes a "purchase schedule" to be mocked to reduce the price of farmers' tobacco [4].

The internal and external problems depress tobacco prices. This condition leads to the practice of a high-cost economy. Tobacco trading system should provide more justice and welfare for farmers. Although tobacco is not included as the agricultural commodity and strategic food, this is a leading commodity in Indonesia. Regulation on the determination of production costs is needed especially for the purpose of improvement and productivity [2]. Such protection is indeed supposed to be accepted by farmers as a means to empower and improve their lives. The issuance of Law No. 19 of 2013 provides guarantees for the protection and empowerment of farmers that must be carried out by the government. This law was issued due to a situation where farmers often experience losses caused by both policies and natural conditions. Furthermore, this Law has the objectives of: (1) promoting the independence of farmers in order to improve the level of welfare, quality and life, (2) providing agricultural infrastructure and facilities needed in the development of farming, (3) providing farming certainty by protecting farmers from price fluctuations, high cost economic practices and crop failures, (4) improving the ability and capacity of farmers and farmer institutions in carrying out productive, advanced, modern and sustainable farming, and (5) developing agricultural financing institutions. 
PRGississuance of the law guarantees Advances in Engingering price fixing by middlemen. This guarantee is affirmed in Law Number 19 of 2013 Article 66 which states that the government and local government in accordance with their authorities are obliged to facilitate the financing and capital of Farmer Business. This law has not been fully able to free tobacco farmers from the entrapment of trade arrangements that create unbalanced pricing and put them in weak bargaining positions. However, this law provides opportunities that can provide a way to make all efforts to protect and empower farmers [2].

\section{Challenges of Government Policy}

Tobacco farmers face internal and external conditions simultaneously, and this is very unpleasant. The internal issue faced by tobacco farmers is tobacco price fluctuation, causing an increase in production costs and reduce in farmers profits. Regarding the external issue, farmers face very stressful conditions namely the position of middlemen who unilaterally determine the quality, scale, and price of tobacco. The mechanism of the oligopsonistic tobacco trading system enables a number of warehouses owned by a small number of manufacturers to play a role in the "capacity" of the warehouse so that farmers are willing to sell their crops at the cheapest prices, positioning farmers as the disadvantaged party. A situation like this makes a "purchase schedule" to be mocked to reduce the price of farmers' tobacco [4].

Table 1. High-value alternative crops for tobacco

\begin{tabular}{|c|c|c|c|c|c|}
\hline Agroecology & Vegetable & Fruits & $\begin{array}{c}\text { Decorative } \\
\text { plant }\end{array}$ & Plantation & Crops \\
\hline 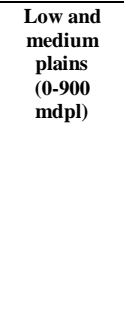 & $\begin{array}{c}\text { Season: } \\
\text { Red Chili } \\
\text { Cayenne } \\
\text { pepper } \\
\text { Red onion } \\
\text { Tomato } \\
\text { Kale } \\
\text { Spinach } \\
\text { Casin } \\
\text { Other } \\
\text { Vegetables }\end{array}$ & $\begin{array}{c}\text { Season: } \\
\text { Watermelon } \\
\text { Melon } \\
\\
\text { Annual: } \\
\text { Durian } \\
\text { Banana } \\
\text { Starfruit } \\
\text { Mangosteen } \\
\text { Orange } \\
\text { Papaya } \\
\text { Guava } \\
\text { Pineapple }\end{array}$ & $\begin{array}{l}\text { Annual: } \\
\text { Orchid } \\
\text { Dracena } \\
\text { Croton } \\
\text { Aloe vera } \\
\text { Jasmine } \\
\text { Palm } \\
\text { Suplir }\end{array}$ & $\begin{array}{c}\text { Annual: } \\
\text { Cane } \\
\text { Cocoa } \\
\text { Vanilla } \\
\text { Coffee } \\
\text { Medicinal } \\
\text { plants }\end{array}$ & Corns \\
\hline $\begin{array}{c}\text { Plateu (> } \\
900 \text { mdpl) }\end{array}$ & $\begin{array}{c}\text { Season: } \\
\text { Red chili } \\
\text { Potato } \\
\text { Tomato } \\
\text { Cabbage } \\
\text { Spring onion } \\
\text { Carrot } \\
\text { Cauliflower } \\
\text { Broccoli } \\
\text { Asparagus } \\
\text { Celery }\end{array}$ & $\begin{array}{l}\text { Season: } \\
\text { Melon } \\
\text { Annual: } \\
\text { Strawberry } \\
\text { Tangerine } \\
\text { Lime } \\
\text { Siam orange }\end{array}$ & $\begin{array}{c}\text { Annual: } \\
\text { Chrysanthe } \\
\text { mum } \\
\text { Rose } \\
\text { Lili } \\
\text { Orchid } \\
\text { Gladiol } \\
\text { Phalaenopsis } \\
\text { Tuberose } \\
\text { Soka } \\
\text { Carnation }\end{array}$ & $\begin{array}{l}\text { Annual: } \\
\text { Coffee } \\
\text { Medicinal } \\
\text { plants }\end{array}$ & \\
\hline
\end{tabular}

Source: FKM UI, 2012.

The internal and external problems depress tobacco prices. This condition leads to the practice of a high-cost economy. Tobacco trading system should provide more justice and welfare for farmers. Although tobacco is not included as the agricultural commodity and strategic food, this is a leading commodity in Indonesia. Regulation on the determination of production costs is needed especially for the purpose of improvement and productivity [2]. Such protection is indeed supposed to be accepted by farmers as a means to empower and improve their lives. The issuance of Law No. 19 of 2013 provides guarantees for the protection and empowerment of farmers that must be carried out by the government. This law was issued due to a situation where
Resegrch, yqlume 172 expence losses caused by both policies and natural conditions. Furthermore, this Law has the objectives of: (1) promoting the independence of farmers in order to improve the level of welfare, quality and life, (2) providing agricultural infrastructure and facilities needed in the development of farming, (3) providing farming certainty by protecting farmers from price fluctuations, high cost economic practices and crop failures, (4) improving the ability and capacity of farmers and farmer institutions in carrying out productive, advanced, modern and sustainable farming, and (5) developing agricultural financing institutions.

The issuance of the law guarantees farmers to face the price fixing by middlemen. This guarantee is affirmed in Law Number 19 of 2013 Article 66 which states that the government and local government in accordance with their authorities are obliged to facilitate the financing and capital of Farmer Business. This law has not been fully able to free tobacco farmers from the entrapment of trade arrangements that create unbalanced pricing and put them in weak bargaining positions. However, this law provides opportunities that can provide a way to make all efforts to protect and empower farmers [2].

\section{CONCLUSION}

The oligopsony and monopsony tobacco trading systems have currently placed tobacco farmers in a weak bargaining position. The price of tobacco leaves is determined unilaterally by the tobacco industry. Government regulations have not been effective enough to either reduce the dominance of the tobacco industry in the chain of tobacco trading systems or provide protection for tobacco farmers. The regulations have not optimally promoted tobacco farmers to have a higher bargaining position and certainty in carrying out their farming business. The absence of regulations regarding price fixing and purchase schedule has created two problems for tobacco farmers, namely: (1) the tobacco industry has a very strong bargaining position because it rules the tobacco pricing since the government does not act as a price regulator; and (2) tobacco farmers will only be able to sell their tobacco if tobacco factory opens purchase.

Tobacco farmers face internal and external conditions simultaneously, and this is very unpleasant. The internal issue faced by tobacco farmers is tobacco price fluctuation, causing an increase in production costs and reduction profits for farmers. Tobacco farmers are at the lowest position in tobacco trading system chain, becoming the most disadvantaged and exploited by tobacco industries. The government shall make efforts to protect and empower tobacco farmers by optimizing the implementation of laws that are relevant, such as Law No. 19 of 2013 concerning Farmer Protection and Empowerment, Law Number 39 of 2007 concerning Excise Tax, Law Number 6 of 2014 concerning Villages, Law Number 23 of 2014 concerning Local Government, Law Number 7 of 2014 concerning Trade, Law Number 1 of 2013 concerning Microfinance Institutions, and Law Number 13 of 2011 concerning Handling of Poor People. In addition, the government 

using two simultaneous strategies, namely: (a) pushing tobacco plants by promoting competitive alternative crops (push factor), and (b) pulling tobacco plants by reducing tobacco demand by industry (pull factor).

\section{ACKNOWLEDGMENT}

The author thanks Universitas Muhammadiyah Yogyakarta for the support in conducting this study. Support from Dr. Sukamto (Vice Rector) and Research Institution of Universitas Muhammadiyah Yogyakarta is acknowledged.

\section{REFERENCES}

[1] T. IAKMI, Atlas Tembakau Indonesia. Jakarta: TCSC-IAKMI, 2013.

[2] S. Markus et al., Petani Tembakau di Indonesia: Sebuah Paradoks Kehidupan. Jakarta: Indonesian Institute for Social Development, 2015.

[3] F. U. UI, Substitusi Tanaman Tembakau Dalam Pengendalian Bahaya Merokok, 2nd ed. Jakarta: Unit pengendalian Tembakau FKM UI, 2012.

[4] W. Prasetyo, "Paradoks Ganda Kos Produksi Petani Tembakau (Studi Fenomenologi Pada Petani Tembakau Di Kabupaten Jember)," $J$. Ekon. dan Bisnis, vol. 20, no. 1, pp. 67-82, 2017.

[5] K. Pendidikan, "Kamus Besar Bahasa Indonesia Daring." .

[6] G. El Guyanie, Ironi Cukai Tembakau, Karur-Marut Hukun \& Pelaksanaan Dana Bagi Hasil Cukai Hasil Tembakau di Indonesia. Jakarta: Indonesia Berdikari, 2013.

[7] A. Jayadi and T. Arbiansyah, Sengsara di Timur Jawa: Kisah Ketidakberdayaan Para Petani Tembakau Sumenep, Pamekasan, dan Jember. Jakarta: Yayasan Indonesia Sehat, 2012.

[8] Solfiyah, "Permasalahan dan Tantangan Pertanian Tembakau serta Solusinya," Bogor, 2014.

[9] D. Rokhmah, "Analisis Faktor Risiko Green Tobacco Sickness (GTS) dan Metode Penanganannya Pada Petani Tembakau," Universitas Jember, 2014. .

[10] M. Rachmad, "Mengerdilkan tembakau: Petani tembakau belum menjadi prioritas," Mengerdilkan tembakau: Petani tembakau belum menjadi prioritas, vol. 26, no. 30, 2015.

[11] D. Firmansyah, "Analisis Pemasaran Tembakau Rajangan di Kabupaten Boyolali,” Universitas Sebelas Maret, Boyolali, 2010.

[12] K. B. Andri, "Analisa Manajemen rantai Pasok Agribisnis Tembakau Selopuro Blitar Bagi Kesejahteraan Petani Lokal," Universitas Trunojoy, 2012. [Online]. Available: http:pertanian.trunojoyo.ac.id.

[13] R. H. Hammam, "Proses Pemasaran Hasil Pertanian Tembakau (Studi Kasus Pada Proses Pemasaran Hasil Pertanian Tembakau di Desa Mandisari Kecamatan Parakan Kabupaten Temanggung)," Universitas Negeri Yogyakarta, 2015. 